\title{
An Apparent Inhibition of Insulin Biosynthesis Resulting from Inhibition of Transport of Neutral Amino Acids by Arginine
}

\author{
B. J. Lin \\ Department of Physiology, University of Toronto, Toronto, Ontario, Canada
}

\begin{abstract}
Summary. At concentrations higher than $10 \mathrm{mM}$, the cationic amino acid, arginine, inhibited the incorporation of the neutral amino acids such as alanine, threonine, valine and leucine into insulin in the presence of glucose. This inhibitory effect probably did not result from the stimulatory effect of arginine on insulin release because, in the absence of glucose, arginine failed to stimulate insulin release but nevertheless inhibited the incorporation of leucine into insulin. This inhibitory effect of arginine was shared by another basic amino acid, histidine, but not by lysine. Arginine inhibited the incorporation of leucine not only into insulin but also into other islet proteins. This inhibition was not accompanied by any disturbance of glucose metabolism in the islet cells. Further studies indicated that the inhibition of incorporation resulted primarily from the interference of uptake of the neutral amino acids by arginine.
\end{abstract}

Key words: Pancreatic islet, insulin secretion, insulin biosynthesis, amino acids, transport.

Arginine is a potent stimulus for the secretion of insulin [1], glucagon [2] and growth hormone [3]. Because of the close relationship that exists between the mechanisms for the biosynthesis and the secretion of insulin, it was decided to investigate the effect of arginine on insulin biosynthesis. Since the cationic amino acid arginine had not been known to impede the uptake of the neutral amino acids in other tissues, we used tritium-labelled leucine to determine the rate of insulin biosynthesis in the presence of arginine. Our initial experiment disclosed a strong inhibition of leucine incorporation in the presence of arginine [4]. This was rather surprising and we initiated a series of experiments to elucidate the mechanism of this inhibition. A preliminary account of this investigation was presented at the annual meeting of the Royal College of Physicians and Surgeons of Canada [5].

\section{Materials and Methods}

Islets of Langerhans were isolated by a collagenase method from male Wistar rats, which were fed ad lib. and weighing approximately $500 \mathrm{~g}$ [6]. Usually 10 to 20 islets were incubated in $0.1 \mathrm{ml}$ of Krebs-Ringer bicarbonate solution containing bovine serum albumin (1 mg/ml, fraction V, Sigma Chemical Co.). Glucose, $\mathrm{L}-\left[4,5-{ }^{3} \mathrm{H}\right]$ leucine $(30-64 \mathrm{Ci} / \mathrm{mmole}$; generally $5 \mu \mathrm{Ci}$ per incubation tube; New England Nuclear Corp.), L- $\left[3-{ }^{3} \mathrm{H}\right]$ alanine $(13.2 \mathrm{Ci} / \mathrm{mmole}, 5 \mu \mathrm{Ci}$ per incubation tube; New England Nuclear Corp.), $\mathrm{L}-\left[\mathrm{G}-{ }^{3} \mathrm{H}\right]$ threonine $(2.38 \mathrm{Ci} / \mathrm{mmole}, 5 \mu \mathrm{Ci}$ per tube, New England Nuclear Corp.) L- $\left[\mathrm{G}-{ }^{3} \mathrm{H}\right]$ valine $(0.8 \mathrm{Ci} /$ mmole, $5 \mu \mathrm{Ci}$ per tube, New England Nuclear Corp.), $\left[\mathrm{U}-{ }^{14} \mathrm{C}\right]$ sucrose $(10 \mathrm{mCi} / \mathrm{mmole}$, Amersham/Searle Corp.) and various unlabelled amino acids (all from Sigma Chemical Co.) were added as indicated. After 1 to $2 \mathrm{~h}$ of incubation at $37^{\circ} \mathrm{C}$ under constant gassing with $5 \% \mathrm{CO}_{2}$ in oxygen in a Dubnoff shaking incubator, islets were extracted with acid alcohol by Davoren's method and proinsulin was separated from insulin by polyacrylamide gel electrophoresis as described before [7]. In some experiments, in order to assess the amount of $\left[{ }^{3} \mathrm{H}\right]$ leucine incorporated into proteins other than proinsulin and insulin, $0.1 \mathrm{ml}$ of $10 \%$ trichloracetic acid (TCA) was added at the end of the incubation period. After mixing and a brief centrifugation, the mixture was heated at $95^{\circ} \mathrm{C}$ for 15 min. The precipitate was washed twice with $5 \%$ TCA and was homogenized with a glass pestle. As the pestle was being withdrawn, 0.1 to $0.2 \mathrm{ml}$ of acid alcohol, 
containing $1 \mathrm{mg}$ of bovine insulin, was added. The entire acid alcohol mixture was applied on a column $(9 \times 600 \mathrm{~mm})$ of Bio-Gel P30 ( -400 mesh, Bio-Rad Laboratories) and was eluted with $3 \mathrm{M}$ acetic acid. One $\mathrm{ml}$ fractions were collected with LKB UltroRac and absorbance at $280 \mathrm{~nm}$ was read in a Beckman DBG spectrophotometer. The radioactivity of each fraction was counted in $10 \mathrm{ml}$ of Aquasol (New England Nuclear Corp.) with a Nuclear-Chicago Mark II liquid scintillation counter. Quench correction was made by computing the channels ratio on external standard $\left({ }^{133} \mathrm{Ba}\right)$. Radioactivity of proteins other than proinsulin and insulin appeared as a single peak at the void volume.

D-[U- $\left.{ }^{14} \mathrm{C}\right]$ glucose $(3 \mathrm{mCi} / \mathrm{mmol}$, Amersham/ Searle Corp.) was used to measure the rate of oxidation to $\mathrm{CO}_{2}$ by a method previously described [6].

To measure the amount of insulin secreted by the islets, groups of 10 islets each were pre-incubated in $0.5 \mathrm{ml}$ of the basic medium (Krebs-Ringer bicarbonate solution with bovine serum albumin, $1 \mathrm{mg} / \mathrm{ml}$ ) for $30 \mathrm{~min}$ under constant shaking and gassing with $5 \% \mathrm{CO}_{2}$ in oxygen at $37^{\circ} \mathrm{C}$. The pre-incubation medium was removed and was immediately replaced with $0.5 \mathrm{ml}$ of basic medium with or without glucose, arginine and leucine. Islets were incubated further for $60 \mathrm{~min}$. The medium was assayed with a commercial kit (Amersham/Searle Corp.). Rat insulin (Novo) was used as the standard in the assay.

For measuring the initial rate of uptake of leucine or alanine, the method described by Hellman et al. was followed [8]. [U- $\left.{ }^{14} \mathrm{C}\right]$ sucrose was used to estimate the extracellular space. Following a pre-incubation period of $60 \mathrm{~min}$ in the basic medium (Krebs-Ringer bicarbonate-BSA) fortified with $3 \mathrm{mM}$ glucose, batches of 2 to 3 very large rat islets (total dry weight: 4 to $5 \mu \mathrm{g}$ ) were incubated for $90 \mathrm{sec}$ in $110 \mu \mathrm{l}$ of basic medium containing $\mathrm{L}-\left[4,5-{ }^{3} \mathrm{H}\right]$ leucine or $\mathrm{L}-\left[3-{ }^{3} \mathrm{H}\right]$ alanine with or without arginine. For ease in handling, islets and medium were placed in a $5 \mathrm{ml}$ disposable polypropylene beaker (Fisher Scientific $\mathrm{Co}$.), covered loosely with a sheet of aluminum foil to prevent catching any condensate falling down from the inner surface of the roof of the Dubnoff shaking incubator.

Modified braking pipettes were made from $20 \mu \mathrm{l}$ 'microcaps' disposable micropipettes (Drummond Scientific Co.). The original rubber bulb was replaced by an Adams suction apparatus (Clay Adams, A-2473 (4555)). One end of the pipette was drawn into a fine tip to facilitate complete removal of the incubation medium surrounding islets before lyophilization. Coating of pipettes with silicon solution prevented adhesion of islets. Frozen-dried islets were weighed on a Mettler UM-7 ultramicrobalance. After weigh- ing, islets were wetted with a few $\mu$ l of water and were immediately dissolved in $100 \mu \mathrm{l}$ of Nuclear-Chicago solubilizer (NCS). Islets dissolved completely within a few minutes at $22^{\circ} \mathrm{C}$ (islets dissolved very slowly unless wetted with water first). The radioactivity was counted in $10 \mathrm{ml}$ of toluene-based scintillator as described before [6].

In one series of experiments, in which the effect of arginine on leucine incorporation beyond the transport step was investigated, the total amount of leucine incorporated into proinsulin and insulin was assayed by a sensitive double-antibody immunoprecipitation procedure [9]. Cycloheximide and all unlabelled amino acids were purchased from Sigma Chemical Co.. Dr H.N. Christensen and Dr A.M. Fisher generously supplied GPA (4-amino-1-guanylpiperidine-4carboxylic acid) and bovine insulin, respectively.

\section{Results}

The concentration of $\mathrm{L}-\left[4,5-{ }^{3} \mathrm{H}\right]$ leucine generally used to demonstrate insulin biosynthesis with rat islets is 0.7 to $1.6 \mu \mathrm{M}$. In the presence of $20 \mathrm{mM}$ glucose and $1 \mu \mathrm{M}$ leucine, the addition of $20 \mathrm{mM}$ valine, isoleucine, phenylalanine, arginine or histidine resulted in a significant inhibition of leucine incorporation into proinsulin and insulin ( $t$ test, one tail, $\mathrm{p}<0.01$, Fig. 1). Alanine, methionine, threonine and lysine did not affect leucine incorporation significantly.

Table 1 shows that a significant inhibitory effect on leucine incorporation occurred when the arginine concentration was $15 \mathrm{mM}$ or higher. Since these inhibitory effects occurred at those concentrations that have been shown to stimulate insulin release, it was decided to test the effect of arginine without glucose. It has been reported $[10,11,12]$ that in rabbit pancreas and islets isolated from obese-hyperglycemic mice, arginine does not stimulate insulin release in the absence of glucose. Our experiments with rat islets also showed that in the absence of glucose, arginine failed to stimulate insulin release (Table 2), but at the same time still inhibited leucine incorporation into proinsulin and insulin (1094 \pm 55 without arginine and $470 \pm 60 \mathrm{dpm} / 2 \mathrm{~h} .20$ islets with arginine; mean \pm $\mathrm{SE} ; \mathrm{n}=6$; paired $t$ test: $\mathrm{p}<0.01$ ). This suggested clearly that the inhibitory effect of arginine did not depend upon its stimulatory effect on insulin release. In the presence of $20 \mathrm{mM}$ glucose, $20 \mathrm{mM}$ arginine inhibited leucine incorporation into proinsulin and insulin even when leucine concentration was raised to $20 \mathrm{mM}(47.39 \pm 4.14$ vs. $23.85 \pm 1.92$ pmoles of leucine incorporated $/ 2 \mathrm{~h} .10$ islets in the absence and 


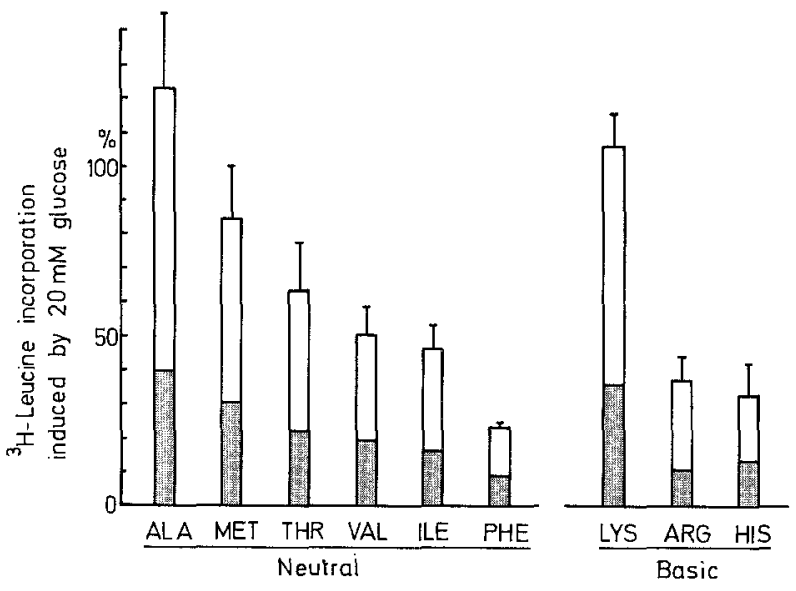

Fig. 1. Batches of 20 islets each were incubated in $1 \mu \mathrm{M}$ $\mathrm{L}-\left[4,5-{ }^{3} \mathrm{H}\right]$ leucine and $20 \mathrm{mM}$ glucose for $2 \mathrm{~h}$. The amount of leucine incorporated into proinsulin and insulin under this basal condition was taken to be $100 \%$. This was inhibited to a varying degree upon addition of unlabelled amino acids ( $20 \mathrm{mM}$ each). Results from several separate experiments were pooled together for ease in comparison. Mean and standard errors of at least 6 repeated experiments are shown. The shaded portion of each bar indicates the amount of insulin, intermediates and $\mathbf{C}$-peptide synthesized; the blank portion indicates the amount of single-chain proinsulin

Table 2. Effect of arginine and leucine on insulin secretion

\begin{tabular}{lrrll}
\hline \multicolumn{2}{l}{ Added to medium $(\mathrm{mM})$} & & $\begin{array}{l}\text { Insulin secreted into medium } \\
(\mu \mathrm{U} / \mathrm{h} .10 \text { islets; Mean } \pm \mathrm{SE})\end{array}$ \\
\cline { 1 - 2 } Glucose & Arg & Leu & \\
\hline 0 & 0 & 0 & $236 \pm 75($ Control $)$ \\
0 & 20 & 0 & $201 \pm 56(\mathrm{p}>0.05)$ \\
0 & 0 & 20 & $434 \pm 45(\mathrm{p}<0.01)$ \\
0 & 20 & 20 & $433 \pm 59(\mathrm{p}<0.05)$ \\
20 & 0 & 0 & $474 \pm 97(\mathrm{p}<0.05)$ \\
\hline
\end{tabular}

Table 1. Effect of arginine on glucose-induced leucine incorporation into proinsulin and insulin

\begin{tabular}{|c|c|c|c|}
\hline \multicolumn{2}{|c|}{$\begin{array}{l}\text { Added to medium } \\
(\mathrm{mM})\end{array}$} & \multirow{2}{*}{$\begin{array}{l}{\left[{ }^{3} \mathrm{H}\right] \text { Leu incorporation into }} \\
\text { (pro)insulin }{ }^{a} \\
\text { (dpm/2 h. } 10 \text { islets) }\end{array}$} & \multirow[t]{2}{*}{ Significance ${ }^{\mathrm{b}}$} \\
\hline Arginine & Glucose & & \\
\hline 0 & 16.7 & $73110 \pm 8230$ & \\
\hline 5 & 16.7 & $84494 \pm 17545$ & n.s. \\
\hline 10 & 16.7 & $66050 \pm 10755$ & n.s. \\
\hline 15 & 16.7 & $47268 \pm 6184$ & $\mathrm{p}<0.05$ \\
\hline 20 & 16.7 & $21300 \pm 3733$ & $\mathrm{p}<0.01$ \\
\hline 25 & 16.7 & $35089 \pm 5206$ & $p<0.01$ \\
\hline
\end{tabular}

a $\quad$ Mean $\pm \mathrm{SE} ; \mathrm{n}=6$

b Compared to glucose alone

Table 3. Comparison of the inhibitory effect of GPA and arginine on insulin biosynthesis

\begin{tabular}{|c|c|c|}
\hline Added to medium & $\begin{array}{l}\text { Leu incorporation into } \\
\text { (pro)insulin } \\
\left(^{(d p m / 2 h . ~} 20 \text { islets) }\right.\end{array}$ & $\begin{array}{l}\text { Significance } \\
(t \text { test })\end{array}$ \\
\hline Glucose, $16.7 \mathrm{mM}$ & $43907 \pm 5811[14]$ & \\
\hline Glucose + GPA, $20 \mathrm{mM}$ & $27854 \pm 7280[8]$ & $0.2>p>0.1$ \\
\hline Glucose + Arg, $20 \mathrm{mM}$ & $13193 \pm 2743[14]$ & $\mathrm{p}<0.001$ \\
\hline
\end{tabular}

Table 4. Effect of arginine on incorporation of certain neutral amino acids into 1 . insulin, intermediates and C-peptide (IC), and 2. single-chain proinsulin (SP)

\begin{tabular}{|c|c|c|c|c|c|c|c|}
\hline \multicolumn{2}{|c|}{ Added to medium } & \multicolumn{6}{|c|}{ Rate of incorporation (dpm/2 h. 20 islets) } \\
\hline \multirow{2}{*}{$\begin{array}{l}\text { Arginine } \\
(\mathrm{mM})\end{array}$} & \multirow{2}{*}{$\begin{array}{l}\text { Glucose } \\
(\mathrm{mM})\end{array}$} & \multicolumn{2}{|c|}{$\mathrm{L}-\left[3-{ }^{3} \mathrm{H}\right]$ alanine $(\mathrm{n}=6)$} & \multicolumn{2}{|c|}{$\mathrm{L}-\left[\mathrm{G}-{ }^{3} \mathrm{H}\right]$ valine $(\mathrm{n}=8)$} & \multicolumn{2}{|c|}{$\mathrm{L}-\left[\mathrm{G}-{ }^{3} \mathrm{H}\right]$ threonine $(\mathrm{n}=8)$} \\
\hline & & SP & IC & $\mathrm{SP}$ & IC & $\mathrm{SP}$ & $\mathrm{IC}$ \\
\hline 0 & 0 & $286 \pm 16^{\mathrm{a}}$ & $498 \pm 28^{a}$ & $72 \pm 15^{\mathrm{a}}$ & $85 \pm 14^{a}$ & $64 \pm 11^{\mathrm{a}}$ & $74 \pm 11^{\mathrm{a}}$ \\
\hline 20 & 20 & $879 \pm 168^{\mathrm{a}}$ & $2749 \pm 433^{a}$ & $944 \pm 403^{b}$ & $2125 \pm 900^{b}$ & $242 \pm 59^{\mathrm{a}}$ & $560 \pm 202^{\mathrm{a}}$ \\
\hline 1 & 20 & $4160 \pm 874$ & $10168 \pm 1970$ & $3988 \pm 762$ & $7867 \pm 1889$ & $1390 \pm 147$ & $2691 \pm 325$ \\
\hline 0 & 20 & $5262 \pm 297$ & $13171 \pm 434$ & $3600 \pm 1059$ & $6595 \pm 1562$ & $1684 \pm 234$ & $3556 \pm 568$ \\
\hline
\end{tabular}

${ }^{\mathrm{a}} \mathrm{p}<0.01 ;{ }^{\mathrm{b}} \mathrm{p}<0.05 ;$ compared to glucose alone 
presence of arginine, respectively; mean $\pm S E$; $n=9$; $\mathrm{p}<0.01$ ). Since glucose provides fuels necessary for the biosynthesis of insulin, the rate of glucose metabolism in islet cells was examined, and it was found that the rate of oxidation of glucose $(16.7 \mathrm{mM})$ was not appreciably inhibited by $20 \mathrm{mM}$ arginine (594 \pm 139 without arginine and $523 \pm 115$ with arginine; pmoles of glucose oxidized to $\mathrm{CO}_{2} / 2 \mathrm{~h}$. 10 islets; mean $\pm S E ; n=6$ ).

GPA, a model substrate for the transport system for cationic amino acids, did not inhibit leucine incorporation into proinsulin and insulin as strongly as arginine (Table 3 ).

Arginine (20 mM but not $1 \mathrm{mM}$ ) not only inhibited the incorporation of leucine into insulin, but also inhibited the incorporation of $\mathrm{L}-\left[3-{ }^{3} \mathrm{H}\right]$ alanine, $\mathrm{L}-\left[\mathrm{G}-{ }^{3} \mathrm{H}\right]$ threonine and $\mathrm{L}-\left[\mathrm{G}-{ }^{3} \mathrm{H}\right]$ valine (Table 4 ) into insulin when these amino acids were present in trace quantity in the incubation medium.

The inhibitory effect of arginine on leucine incorporation was not limited to insulin and proinsulin alone; leucine incorporation into other islet proteins was also inhibited (Table 5).

In order to elucidate further the mechanism of inhibition by arginine, the initial rate of uptake of leucine by islet cells was measured. This was found to be strongly inhibited (Table 6). The initial rate of uptake of alanine was only half as fast as leucine in spite of the higher initial concentration (3.4 against 1 $\mu \mathrm{M}$ ); nevertheless, $20 \mathrm{mM}$ arginine inhibited alanine uptake also (Table 6).

Although the inhibition of uptake of the neutral amino acids by arginine seemed to account fully for its inhibitory effect on incorporation, in order to ensure that steps of biosynthesis subsequent to uptake were not inhibited by arginine, a series of experiments were carried out. Three batches of islets were incubated in media containing $5.5 \mathrm{mM}$ glucose and $1.5 \mu \mathrm{M}$ $\mathrm{L}-\left[4,5-{ }^{3} \mathrm{H}\right]$ leucine at $37^{\circ} \mathrm{C}$. To ensure the accumulation of free leucine, $0.9 \mathrm{mM}$ cycloheximide was also added to the medium. Cycloheximide and labelled leucine were washed away at the end of $1 \mathrm{~h}$ and islets were incubated for an additional h with $20 \mathrm{mM}$ glucose, with or without $20 \mathrm{mM}$ arginine. The amount of leucine incorporated into proinsulin and insulin in the absence and presence of arginine was $1223 \pm 81$ and $1105 \pm 54 \mathrm{dpm} / 10$ islets, respectively (Mean $\pm \mathrm{SE}$; $\mathrm{N}=12$ ). The difference was not significant. The incorporation of leucine into proinsulin and insulin in the control islets was $508 \pm 78 \mathrm{dpm} / 10$ islets during the first $h$. In the preliminary experiments in which cycloheximide was not added during the first $h$ of incubation, free $\left[{ }^{3} \mathrm{H}\right]$ leucine did not accumulate in the islet cells.
Table 5. Inhibitory effect of arginine on the synthesis of all islet proteins. Total islet proteins were applied on a column of Bio-Gel $\mathrm{P} 30$. The radioactivity of islet proteins other than proinsulin $(\mathrm{P})$ and insulin (I) appeared as a single peak (EP) at the void volume

\begin{tabular}{llll}
\hline \multicolumn{3}{c}{$\begin{array}{l}\left.\text { L-[4,5- }{ }^{3} \mathrm{H}\right] \text { leucine incorporation } \\
\text { (dpm/h. 10 islets) }\end{array}$} & \\
\cline { 2 - 4 } $\begin{array}{l}\text { Arginine } \\
(\mathrm{mM})\end{array}$ & 0 & 20 & \\
$\begin{array}{l}\text { glucose } \\
(\mathrm{mM})\end{array}$ & 20 & 20 & Significance \\
& $(\mathrm{n}=3)$ & $(\mathrm{n}=5)$ & \\
\hline EP & $41183 \pm 4944$ & $19356 \pm 213$ & $\mathrm{p}<0.01$ \\
$\mathrm{P}$ & $118725 \pm 7779$ & $35083 \pm 2413$ & $\mathrm{p}<0.01$ \\
I & $23734 \pm 1940$ & $7374 \pm 734$ & $\mathrm{p}<0.01$ \\
\hline
\end{tabular}

Table 6. Effect of arginine on the initial rate of uptake of leucine and alanine by the pancreatic islets. The initial concentrations of leucine and alanine in the medium were 1 and $3.4 \mu \mathrm{M}$, respectively. Although $3 \mathrm{mM}$ glucose was present during the 60 -min preincubation period, no glucose was added during the 90-s test period

\begin{tabular}{llll}
\hline & \multicolumn{2}{l}{$\begin{array}{l}\text { Initial rate of uptake } \\
(\mu \text { moles } / \mathrm{kg} \text { dry weight. 90 s) }\end{array}$} \\
\cline { 2 - 4 } & $\begin{array}{l}\text { Without } \\
\text { arginine }\end{array}$ & $\begin{array}{l}\text { With } 20 \mathrm{mM} \\
\text { arginine }\end{array}$ & Significance \\
\hline Alanine $(\mathrm{n}=6)$ & $4.32 \pm 1.32$ & $1.50 \pm 0.49$ & $\mathrm{p}<0.05$ (one tail) \\
Leucine $(\mathrm{n}=14)$ & $9.99 \pm 2.03$ & $1.98 \pm 0.54$ & $\mathrm{p}<0.01$ \\
\hline
\end{tabular}

\section{Discussion}

Oxender and Christensen showed [13] that Ehrlich ascites cells possessed two distinct but heavily overlapping transport systems for the neutral amino acids. The existence of the alanine-preferring A system and leucine-preferring $\mathrm{L}$ system was confirmed in pancreatic islets isolated from the obese-hyperglycemic mouse by Hellman et al. [14]. Because of our experimental conditions of very low leucine concentration and very high concentration of the test amino acids in the incubation medium (Fig. 1), the magnitude of inhibition of leucine incorporation into insulin was roughly parallel to the known affinity of various neutral amino acids for the $\mathrm{L}$ system. These experiments served to indicate, albeit indirectly, that the $\mathrm{A}$ and $\mathrm{L}$ systems also exist in the rat islets.

Cationic and neutral amino acids are normally transported separately by their respective transport systems. However, certain unusual exceptions have been reported. For example, the lysine-preferring $\mathrm{Ly}^{+}$system [15] has some affinity for the neutral 
amino acids, such as phenylalanine, if the sodium ion level is sufficiently high [16]. $\mathrm{Na}$ ions make the $\mathrm{Ly}^{+}$ carrier available for the neutral amino acid by occupying the site normally occupied by the $\varepsilon$-amino group of lysine. Although lysine did not inhibit the uptake of phenylalanine or leucine by the rabbit reticulocyte [15], it was reported to inhibit the uptake of $\alpha$-aminoisobutyric acid (AIB) by the islets from the obese hyperglycemic mice [17]. AIB is a model amino acid transported by the A system. Based on Christensen's data, Heinz [16] suggested that the basic amino acids inhibit the $L$ system only when they are present in the neutral form, e.g., after the $\varepsilon$-amino group of lysine has lost its proton. If this be true, it would be difficult for both arginine and lysine to inhibit the $\mathrm{L}$ system at physiological $\mathrm{pH}$, because the $\mathrm{pKa}$ of the guanidino group of arginine is 12.5 , and the pKa of the $\varepsilon$-amino group of lysine is 10.5 . Our results with lysine and arginine (Fig. 1) cannot be explained by this concept if we assume that our data on leucine incorporation into insulin faithfully reflect the rate of leucine uptake. Arginine inhibited leucine incorporation strongly while lysine did not. Schatz et al. also found that arginine but not lysine inhibited the incorporation of leucine induced by glucose $(18,19)$, although Niki et al. found that both lysine and arginine inhibited the incorporation of leucine [20]. The exact mechanism by which arginine inhibits the transport of the neutral amino acids remains to be elucidated. Although Schatz et al. $[18,19]$ observed an inhibitory effect of arginine on leucine incorporation in the presence of glucose ( 1 and $3 \mathrm{mg} / \mathrm{ml}$ ), they failed to observe such an effect in the absence of glucose. With the gel filtration method they used to separate proinsulin from insulin, it is possible that when the rate of incorporation of the labelled amino acid is very low, it becomes rather difficult to quantitate accurately.

The magnitude of inhibition of leucine and alanine uptake approximately equalled the magnitude of inhibition of leucine and alanine incorporation into (pro)insulin. This suggested that arginine inhibited leucine and alanine incorporation into (pro)insulin mainly by inhibiting the uptake of the neutral amino acids and any inhibitory effect on the steps of biosynthesis beyond membrane transport should be minimal. This was found to be true with our experiment with cycloheximide. Since $5 \mathrm{mM}$ arginine did not inhibit the incorporation of $1 \mu \mathrm{M}$ leucine, but $20 \mathrm{mM}$ arginine inhibited the incorporation of both $1 \mu \mathrm{M}$ and $20 \mathrm{mM}$ leucine, and since arginine at concentrations greater than $10 \mathrm{mM}$ inhibited leucine incorporation in a dose-dependent manner, it can be surmised that the $\mathrm{Ly}^{+}$system is mainly responsible for transporting arginine at physiological concentrations, but the $\mathrm{A}$ and

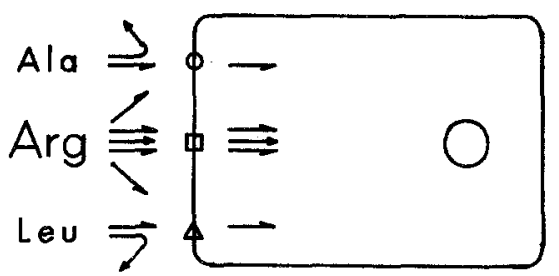

Fig. 2. Amino acid uptake by a B-cell. Arginine is mainly transported by a system specific for cationic amino acids. At concentrations greater than $10 \mathrm{mM}$, arginine interferes with the transport of the neutral amino acids through both $\mathrm{A}$ and $\mathrm{L}$ systems

L systems for the neutral amino acids may transport a significant fraction of arginine at high concentrations, $\mathrm{Km}$ for arginine in the latter systems being in excess of $10 \mathrm{mM}$. This is schematically shown in Figure 2. Further studies of transport kinetics are required to elucidate the exact mode of this inhibition.

Christensen and Cullen observed increases in plasma insulin level and lowering of blood glucose after intraperitoneal injection of a nonmetabolizable model amino acid specific for $\mathrm{L}$ system (2-aminobicyclo [2,2,1] heptane-2-carboxylic acid; $\mathrm{BCH})$. They proposed that the receptor sites for the stimulation of insulin release may be the transport sites [21]. However, Lernmark [11] found that isoleucine did not inhibit insulin release induced by leucine, and that D-leucine did not stimulate insulin release although both $\mathrm{D}$-and L-leucine were transported into the islet cells of the obese hyperglycemic mice [8]. Moreover, D-leucine failed to inhibit insulin release induced by L-leucine [8]. In the present investigation, $20 \mathrm{mM}$ arginine did not inhibit insulin release induced by $20 \mathrm{mM}$ leucine (Table 2), although $20 \mathrm{mM}$ arginine inhibited the incorporation of leucine (20 $\mathrm{mM}$ ) into insulin in the presence of $20 \mathrm{mM}$ glucose. Provided that the inhibition of leucine incorporation resulted from the inhibition of leucine uptake, our data would support Lernmark [11] and Hellman et al. [8] and suggest that the receptor site for signalling insulin release in response to L-leucine is perhaps not identical with the receptor site of transport system $\mathrm{L}$.

Acknowledgement. This paper is dedicated to Dr. R.E. Haist on his retirement. I should like to thank Peter F. Zucker for producing and titrating antibodies used for the immunoprecipitation method, Barbara $\mathrm{R}$. Nagi and Judy Alleyne for their skillful technical assistance. I also thank Kathryn Flattery, Donaleen Bourgeois and Pam Giroux for the secretarial help. This work was supported by a grant from the Medical Research Council of Canada (MA-868). 


\section{References}

1. Malaisse, W.J.: Hormonal and environmental modification of islet activity. In: Handbook of physiology, section 7, Endocrinology, Vol. 1, Endocrine pancreas (eds. D.F. Steiner, N. Freinkel), p. 237. Washington, D.C.: American Physiological Society 1972

2. Unger, R.H., Lefèbvre, P.J.: Glucagon physiology. In: Glucagon (eds. P.J. Lefèbvre, R.H. Unger), p. 213. Oxford: Pergamon Press 1972

3. Merimee, T.J., Lillicrap, D.A., Rabinowitz, D.: Effect of arginine on serum levels of human growth-hormone. Lancet 1965 II, $668-670$

4. Lin, B.J., Haist, R.E.: Effects of certain amino acids on the incorporation of leucine into proinsulin and insulin. Diabetes 22 (Suppl. 1), 323-323 (1973)

5. Lin, B.J., Haist, R. E.: The mechanism of inhibition of insulin biosynthesis by arginine. Ann. roy. Coll. Phys. Surg. Can. 8, 21-21 (1975)

6. Lin, B.J., Haist, R. E.: Respiration and insulin synthesis in the islets of Langerhans. Canad. J. Physiol. Pharmacol. 49, 559-567 (1971)

7. Lin, B.J., Haist, R.E.: Effects of some modifiers of insulin secretion on insulin biosynthesis. Endocrinology 92, 735-742 (1973)

8. Hellman, B., Sehlin, J., Täljedal, I.-B.: Transport of L-leucine and D-leucine into pancreatic cells with reference to the mechanisms of amino acid-induced insulin release. Biochim. biophys. Acta. (Amst.) 266, 436-443 (1972)

9. Zucker, P., Logothetopoulos, J.: Persisting enhanced proinsulin-insulin and protein biosynthesis $\left({ }^{3} \mathrm{H}\right.$-leucine incorporation) by pancreatic islets of the rat after glucose exposure. Diabetes 24, 194-200 (1975)

10. Milner, R.D.G.: Stimulation of insulin release by essential amino acids from rabbit pancreas in vitro. J. Endocr. 47, 347-356 (1970)

11. Lernmark, A.: Effects of neutral and dibasic amino acids on the in vitro release of insulin. Hormones 3, 22-30 (1972)
12. Edgar, P., Rabinowitz, D., Merimee, T.J., Almogela, E.: Effect of arginine on insulin release in vitro. Metabolism 18, 84-86 (1969)

13. Oxender, D.L., Christensen, H.N.: Distinct mediating systems for the transport of neutral amino acids by the Ehrlich cell. J. biol. Chem. 238, 3686-3699 (1963)

14. Hellman, B., Sehlin, J., Täljedal, I.-B.: Uptake of alanine, arginine and leucine by mammalian pancreatic beta-cells. Endocrinology 89, 1432-1439 (1971)

15. Christensen, H.N., Liang, M.: Transport of diamino acids into the Ehrlich cell. J. biol. Chem. 241, 5542-5551 (1966)

16. Heinz, E.: Transport of amino acids by animal cells. In: Metabolic pathways, Vol. VI, Metabolic transport (ed. L. E. Hokin), p. 455. New York: Academic Press 1972

17. Hellman, B., Sehlin, J., Täljedal, I.-B.: Transport of $\alpha$-aminoisobytyric acid in mammalian pancreatic $\beta$-cells. Diabetologia 7, 256-265 (1971)

18. Schatz, H., Hinz, M., Maier, V., Nierle, C., Pfeiffer, E.F.: Amino acids and function of pancreatic islets. Acta Endocr. Suppl. 177, 325-352 (1973)

19. Schatz, H., Nierle, C., Pfeiffer, E. F.: (Pro)insulin biosynthesis and release of newly synthesized (pro)insulin from isolated islets of rat pancreas in the presence of amino acids and sulfonylureas. Europ. J. clin. Invest. 5, 477-485 (1975)

20. Niki, A., Niki, H., Koide, T., Lin, B.J.: Insulin biosynthesis. V. Effects of amino acids, fatty acids and ketone bodies. J. Japan Diab. Soc. Suppl. 17, 21-21 (1974)

21. Christensen, H.N., Cullen, A.M.: Behavior in the rat of a transport-specific, bicyclic amino acid. Hypoglycemic action. J. biol. Chem. 244, 1521-1526 (1969)

Received: August 16, 1976, and in revised form: October 26, 1976

Dr. B.J. Lin

Dept. of Physiology

Univ. of Toronto

Toronto, Ontario M5S 1A8

Canada 